\title{
VIEWS ON HUMAN RIGHTS AMONG CHRISTIAN, MUSLIM AND NON-RELIGIOUS YOUTH IN NORWAY AND SWEDEN ${ }^{1}$
}

Abstract

This study explores the relation between religion and attitudes towards human rights among young people aged 17 to 19 . The data material consists of 1660 questionnaires filled out in the classrooms by upper secondary school pupils living in the capital city of Oslo and in the Stockholm/Uppsala area. We want first to find out if there are closer relations between religion and attitudes towards human rights concerning the private sphere than for attitudes towards human rights concerning the public sphere. By rights related to the private sphere we mean views on abortion and family values and by rights related to the public sphere we mean the right to work, views on social equality, freedom of speech, political interest and environmental protection. The study also looks at differences in this regard between Christians, Muslims and a group of nonreligious. The main result is that while a closer relation can be seen between religion and attitudes concerning the private sphere than attitudes concerning the public sphere, there is no support for the assumption that this relationship is stronger amongst the Muslim sub-group.

Keywords: attitudes, compartmentalisation, differentiation, human rights, religion, youth

\section{Introduction}

During the past 30 years religion has become more visible in the public sphere in the Scandinavian countries (Botvar and Schmidt 2010; Bäckström et al. 2011; Rasmussen 2012). Though historically dominated by Lutheran state churches, immigration of people of non-Lutheran religious traditions has brought new questions to the fore in the public agenda. These are the use of religious symbols among public servants, blasphemy and religious freedom in general. In Scandinavia, religion has been highly privatized and largely kept away from the public sphere (Botvar 1993). This is now being challenged by processes related to globalisation and pluralisation (Bäckström et al. 2011). While the secularisation paradigm still is contested there can be said to exist some consensus surrounding differentiation on a societal level (Pettersson 2009). By this is meant a process of differentiation leading to the separation of different public spheres such as education, the legal system etc. from a religious subsystem. Wilson 
(1966) suggested that following differentiation, religion would continue to play a role in modern society, even though confined to the private sphere. One issue under debate is if the process of differentiation has its parallel on the individual level. The privatisation thesis has been contested by Casanova (1994) who proposed that religious leaders refuse to take the marginal position secular societies reserved for them, thus contributing to a new visibility for religion in highly secularized societies.

Among the proponents of the privatization thesis, Dobbelaere $(1981,1998,2002)$ coined the term compartmentalisation of religion to explain differentiation between religion and other spheres on the individual. He (2002) demonstrated that more religiously involved people had specific and more traditional family values than less religiously involved people, which he explained by the increased privatization of religion, rendering religious values to be relevant only in the realm of private life.

Compartmentalisation has to do with the strategy individuals adopt in order to cope with cross-pressures which occurs when handling different roles that do not fit well together. The concept has been used to describe the increasing division of the lifeworld into several relatively separate sectors or compartments. This process takes place when people make a distinction between their religious faith and their views on political and social issues, such as work roles or political party preferences. Compartmentalisation can thus be seen as the equivalent to differentiation at the societal level. An important distinction can still be made in that compartmentalisation may refer to 1) the extent to which people think that religious commitments should affect political views, or more broadly, that institutional religion should influence political decision making, or 2) the extent to which religious commitments actually have an impact on people's political views (Pettersson 2009). Hence, compartmentalisation is a way of theorizing the continued influence of religion on a micro level.

In this article the views on human rights are seen as a case of political values, which can be related to the theoretical discussion on the impact of religion on political values. As early as 1993 Bryan Turner $(1993,2006)$ highlighted the lack of interest in human rights from sociologists. This article argues that attitudes to human rights are of particular interest for several reasons. One is that human rights are sometimes seen as conflictual to religious traditions. An illustrative example is the Roman Catholic Church's refusal to endorse the declaration of human rights until the Second Vatican Council (1965), and even then only outside the church, not inside (Van der Ven 2010). Another example is Islamic traditions and institutions that are hesitant to accept universal human rights. For instance, the Cairo Declaration on Human Rights in Islam states that «the Islamic Shari' ah is the only source of reference for the explanation or clarification of any of the articles of this Declaration» (Cairo Declaration on Human Rights in Islam 1990). Another interjection to human rights has been the balance between universalism and contextualism, where it is sometimes claimed that human rights would be just another way of imposing Western colonialism on developing countries. A closer understanding of whether religion may function as a support or hinder for human rights at a micro level thus proves relevant. 


\section{Review of the literature}

Pettersson examines compartmentalisation by comparing the attitudes of Christians and Muslims in several countries (Pettersson 2009). According to Pettersson one could expect that compartmentalisation would be more developed among Christians than among Muslims, because Christians living in Western countries have been more exposed to modernisation than Muslims living in other parts of the world. Pettersson studies the impact of religious involvement towards political values, and specifically makes the connection with such political values with universal claims, such as democracy, gender equality, rule of law and human rights. Pettersson's study (2009) used World Values Survey data on a micro level, collected among representative samples of at least 1000 people above the age of 18 per country, i.e. Sweden and Denmark (Christian, Protestant), Spain and Italy (Christian, Catholic), Morocco and Algeria (Islamic, Arabic), Iran and Indonesia (Islamic, non-Arabic). By comparing data from four Muslim countries and four Christian countries, Pettersson found that religious involvement had negative impact on political values (trust in democracy as the best available political system) among the four Christian populations studied only. Religious involvement had no impact on political values among the four Muslim populations. Also, religious involvement was negatively related to the attitude towards gender equality among the European Catholics, but not among the Muslims studied. Pettersson's results repudiate the widespread notion (popular stereotype) of a negative relation between Muslim religiosity and secular values, such as human rights and democracy. His results give some support to the notion that religious involvement may have an impact on political values. It becomes clear however from Pettersson's results that more studies of the compartmentalisation thesis are needed. More research should be conducted in order to reveal the complex interrelations between religious and political values.

Recent studies indicate that the impact of religion on attitudes towards the freedom of religion and freedom of speech specifically is rather limited (Van der Ven 2010; Van der Ven and Ziebertz 2012). This review shows that while previous studies found some evidence of an impact of religion on political values, and in particular attitudes towards different aspects of human rights, two issues still need to be studied more closely: 1) Comparisons between people of different religious traditions and 2) diverse aspects of human rights. It is of specific interest to include such rights that are related to the private sphere (i.e. family values, abortion), and rights that are more applicable to the public sphere (i.e. social equality, protecting the environment).

In a recent Swedish survey of young adults (age 16-24), Lövheim and Bromander (2012) included effects of religion on young people's political attitudes. Using data from this survey, Hagevi (2012) showed that religion may affect young people's political attitudes. The political attitudes examined were sexual equality, gender equality, immigration policy and environment policy. Specifically, the items concerned the rights of same-sex couples to adopt children, equal opportunities of men and women, integration of immigrants into Swedish society, and views on ecology. Hagevi's results indicated a minor effect of religious orientation (Christian, Muslim or Atheist) and religious values (spiritual values rather than materialist values) on political attitudes, even 
when controlled for socioeconomic variables. These results refute a simplistic compartmentalisation hypothesis. There was no effect of religious upbringing and religious participation. From Berglund's (2012) analysis of data from the same survey, complemented with a limited number of interviews, young Swedish Muslims seem to share several values with non-Muslim Swedish youth. Their relation to religion can be characterized as individualized and not so closely linked to organized religion as often claimed.

Very few Norwegian studies have compared political attitudes among young people of different religious background. Most such studies have focused on identity formation in relation to cultural values in society. For example Synnes (2010) compared adaption strategies among young Christians and Muslims in Oslo on the basis of qualitative interview data. He finds that young religious people in Norway simultaneously have an individualized view on religion and are influenced by institutional bounds to religious communities and to their family's religious tradition. In her study of young Muslims in Oslo, Christine Jacobsen (2002) described two important tendencies named «privatization» and «Islamization». Common to these is the increased emphasis on «individual reflection» on religious matters. Religious individualization in young Muslims may thus lead to the view that religious practice is a private matter or to an «orthodox» search for «authentic Islam».

The research project that this article is based on differs from most other Scandinavian studies because it combines a comparison of different life view groups with the use of quantitative data.

\section{Hypotheses}

Against the background outlined above, this article focuses on the relation between religion and political values, as expressed in individual views on human rights. We will examine whether religious beliefs and practices have any impact on attitudes towards human rights, for Christian and Muslim adolescents respectively. We also want to see if religion impacts more strongly on attitudes to rights related to the private sphere than on attitudes to rights related to the public sphere. By rights related to the private sphere we mean approval of abortion and family values and by rights related to the public sphere we mean the right to work, freedom of moral speech, views on social equality, political interest and environmental protection.

1 We will test two hypotheses related to religion and human right attitudes in young people aged 17-19 living in Norway or Sweden: Religion has a larger impact on attitudes related to the private sphere, i.e. abortion and family values, than attitudes related to the public sphere, i.e. social equality and environmental protection.

2 The impact of religiosity on attitudes towards human rights is stronger in the Muslim case than in the Christian one because compartmentalisation is supposed to be stronger in Christian than in Muslim adolescents. 
A stronger impact of religion on an attitude towards human rights is thought to indicate a closer relationship between religion and that particular attitude.

\section{Methods, Materials, Context and Setting}

This article analyses empirical data from Norway and Sweden. The main material consists of questionnaires filled out in the classrooms by upper secondary school pupils (age 17-19) living in the capital city of Oslo and in the Stockholm/Uppsala area. The data was collected in 2007 and 2008. The questionnaire was developed within the international research programme Human Rights and Religion (Van der Ven 2010). Of 1660 questionnaires about 280 were filled out by people who said they belong to an Islamic tradition. About twice that amount belonged to a Christian tradition. A third category consisted of people who regarded themselves to be non-religious. This gave us the opportunity to compare the pattern of compartmentalisation within the three worldview groups.

Seven scales were used as dependent variables: Approval of abortion, Family values, Right to work, Freedom of moral speech, Political interest, Social equality, and Environmentalism. ${ }^{2}$ The operationalisation of these variables will be outlined in the following section. Of these seven items, Approval of abortion and Family values relate more to the private sphere, while Right to work, Moral speech, Political interest, Social equality engagement and Environmentalism can be said to be more related to the public sphere. All of these are not attitudes towards human rights in a strict sense, but work as indicators of attitudes related to the private and public spheres, respectively. They are also relevant to different aspects of human rights, or the three generations of rights, such as civil rights (with moral speech as an example of freedom of speech), social and economic rights (right to work, social equality) and environmental rights as an example of the third generation of rights (Van der Ven 2010). Other items used are relevant to several human rights.

All the scales were constructed using means, with list wise deletion. Approval of abortion was a scale composed of four items: Would you please indicate whether, or to what extent, you think it should be possible for a pregnant woman to obtain a legal abortion if: a) There is a strong chance of serious defect in the baby; b) Financially she cannot afford any more children; c) The woman's own health is seriously endangered by the pregnancy; d) Psychologically she cannot afford any more children. For each situation a-d an answer was given on a 5-point scale, from 1 'I totally disagree' and 5 'I totally agree'. The reliability (Cronbach's alpha) for the scale on abortion was .85.

Family values was a scale composed of three items, asking about how important the respondent finds a) Being married, b) Having children or raising them, and c) Living for your family. For each item a-c the answer was given on a 5-point scale from 1 'Not important at all' to 5 'Very important'. The reliability (Cronbach's alpha) for this scale was .66. This is a bit low but still higher than 0.60 which is often seen as the absolute limit. Work as a right was a scale composed of three items: a) The government should provide a job for everybody who wants one, b) The government should provide a decent standard of living for the unemployed, and c) The state should protect women's 
right to adequate job opportunities. Answers were given on a 5-point scale from 1 'I totally disagree' at all 5 'I fully agree'. The reliability (Cronbach's alpha) for this scale was .80 .

Moral speech was composed using two items, a) The community's moral standards should be critically debated in schools, and b) Children should be free to discuss all moral ideas and subjects in schools, no matter what. For each situation the answer was given on a 5-point scale, from 1 'I totally disagree' to 5 'I totally agree'. For this scale the reliability (Cronbach's alpha) was .62. Social equality was a scale composed of two items, a) Contributing to reduction of existing income differences, and b) Promoting greater equality in society. For each statement an answer was given on a 5-point scale, from 1 'I totally disagree' to 5 'I totally agree'. The reliability (Cronbach's alpha) for this scale was .75. Environmentalism was a scale composed of two items: a) I am willing to pay higher prices for products if that would mean less industrial pollution, and b) I am willing to make certain sacrifices for the sake of a more beautiful environment. For each statement answer was given on a 5-point scale, from 1 'I totally disagree' to 5 'I totally agree'. The reliability (Cronbach's alpha) for this scale was .76.

Studies in a number of Western countries on attitudes toward religion among young people have demonstrated that neither religious participation nor religious knowledge are particularly high (Kay and Ziebertz 2006; Robbins and Francis 2010; Valk et al. 2009; Ziebertz and Kay 2005). This has also been shown in Norway and Sweden where religion is individualised to a greater extent (Lövheim and Bromander 2012). In this study, the independent variable concerning religion for the first part of the analysis was religious self-identification: Christian, Protestant, Catholic, Pentecostal, Other Christian tradition were coded as 'Christian'; Muslim, Sunni, Shia, Other Muslim tradition were coded as 'Muslim'; Non-religious were coded as 'Non-religious'. Other alternatives such as Buddhist did not receive enough responses to be included in the analysis and were therefore omitted.

For the second part of the analysis a religiosity index was used for independent variables concerning religion, and gender, parents' educational level, political conversation at home, and political preferences were used as control variables. The religiosity indexes used, one for Christian religiosity and one for Muslim religiosity, were each constructed out of six items. For the Christian religiosity index, the items were 1) Believes the Bible is the word of God, 2) Frequency of reading the Bible, 3) Sees Jesus as son of God (scale composed of three items, mean for three items is used), 4) Participates in religious services, 5) Frequency of personal prayer, and 6) Self-identification as Christian. The Muslim religiosity index was based on the following items: 1) Believes the Quran is the word of God, 2) Frequency of reading the Quran, 3) Sees Muhammad as God's prophet (scale composed of three items, mean for three items is used), 4) Participates in religious services, 5) Frequency of personal prayer, and 6) Self-identification as Muslim. These indexes range from 0 to 5 . The mean for Christian Religiosity Index was 2.07, standard deviation $=1.13$. The mean for Muslim Religiosity Index was 1.81 , standard deviation $=1.10$.

Multiple regression analysis was used to investigate the direct effect of religiosity after controlling for other relevant variables. In order to further examine the hypotheses 
in this article, Christian Religiosity Index and Muslim Religiosity Index were added to an initial model consisting of social background variables. The statistical method used was «forced entry».

\section{The religiosity of three subgroups}

First the religiosity evident in the three categories of Christians, Muslims and Non-religious was compared. These groups were derived from the self-identification of the respondents. We chose to compare these groups in the categories related to religious beliefs and practices such as regular prayer, regular service attendance, reading of the Bible or the Quran, view of Jesus and Muhammad respectively, and religious saliency. Table 1 shows that while regular prayer and service attendance form part of the life of about every fifth or every fourth of Christians and Muslims, reading of the Bible or the Qur'an respectively was not as frequent. There were also some minor differences between the countries: Christians in Norway pray less frequently than Christians in Sweden, while Muslims in Norway pray more often than their Swedish counterparts. These differences can likely be explained by sampling procedure. Both the Swedish and the Norwegian samples included suburban areas with significant proportions of young people of foreign background (i.e. either the respondent was born outside the country or both of the respondent's parents were born outside the country). The Swedish sample included a number of Assyrians (Orthodox) and Iraqi Catholics, which was not the case in the Norwegian sample. It is also clear from Table 1 that the non-religious self-identification worked well in the sense that the respondents in this group were not religious according to the indicators used here.

Table 1: Religiosity in different groups, compared country wise, Swedish and Norwegian samples. The top four items are in percent and the bottom three items are mean scores

\begin{tabular}{|l|r|r|r|r|r|r|}
\hline & \multicolumn{2}{|c|}{ Christian } & \multicolumn{2}{c|}{ Muslim } & \multicolumn{2}{c|}{ Non-religious } \\
\hline & SWE & NOR & SWE & NOR & SWE & NOR \\
\hline percent base (n=) & 420 & 153 & 111 & 158 & 458 & 190 \\
\hline Prays regularly & 20.2 & 1.3 & 20.7 & 24.7 & 0.7 & 0.7 \\
\hline Religious service weekly & 10.7 & 5.9 & 9.0 & 12.4 & 0.2 & 0.0 \\
\hline Reads Bible regularly & 8.7 & 2.0 & 1.3 & 2.9 & 0.0 & 0.0 \\
\hline Reads Quran regularly & 0.8 & 0.0 & 21.2 & 36.3 & 0.2 & 0.5 \\
\hline Jesus son of God 1-5 & 3.50 & 3.38 & 2.05 & 2.03 & 1.45 & 1.73 \\
\hline Muhammad prophet 1-5 & 1.83 & 2.48 & 4.00 & 4.48 & 1.49 & 1.70 \\
\hline «Religious saliency» 1-5 & 3.24 & 2.84 & 3.92 & 4.17 & 1.68 & 1.69 \\
\hline
\end{tabular}

In the following analyses (tables 2 through 4) we chose to process the data from Sweden and Norway together. The data from the two countries were thus combined. There were two reasons for this mode of operation. One was that there are many basic similarities between the societies when it comes to values (Gustafsson and Pettersson 2000). 
Second, this measure was relevant in order to enable group comparisons with acceptably high level of precision as it makes the groups of comparison larger (Field 2010). In those instances where there are differences between Sweden and Norway, this will be commented in detail.

\section{Results}

\section{Step 1: Comparison of the attitudes in the three groups}

First, the groups Christians, Muslims and Non-religious were compared for their attitudes on a number of issues. For seven studied variables in total we use the means, since these variables are scales, each composed of two to four items. The means run from 1 (disagrees/not important) to 5 (agrees/very important). The question is, do the groups differ, and if so, in what ways?

Table 2: Comparison by religious self-definition groups, aggregated data Sweden and Norway. Mean scores, scales 1-5

\begin{tabular}{|l|r|r|r|r|}
\hline & Christian & Muslim & Non-religious & Sign. \\
\hline & $\mathrm{n}=523-581$ & $\mathrm{n}=247-277$ & $\mathrm{n}=635-660$ & \\
\hline Abortion & 3.63 & 3.34 & 3.95 & $* * *$ \\
\hline Family values & 4.20 & 4.30 & 3.71 & $* * *$ \\
\hline Work as a right & 4.18 & 4.27 & 4.08 & $* * *$ \\
\hline Moral speech & 3.60 & 3.48 & 3.48 & $*$ \\
\hline Politics important & 2.90 & 2.99 & 2.78 & $*$ \\
\hline Social equality & 3.54 & 3.77 & 3.33 & $* * *$ \\
\hline Environment & 3.61 & 3.43 & 3.72 & $* *$ \\
\hline
\end{tabular}

As can be seen in table 2, there were some differences between the Christians and the Muslims on the one hand, and the non-religious group on the other. On abortion, the Muslims were the least positive (3.34), the Christians a little more positive (3.63), while the non-religious were the most positive (3.98). When it comes to family values, the Muslims (4.30) and the Christians (4.20) were more in favour of these than the non-religious (3.71). For the variable right to work there are differences that interestingly go in the opposite direction from that suggested by the hypothesis: Muslims were most in favour of the right to work (4.27), the Christians score second (4.18), and the non-religious were - still on a very high level (4.08) - the least positive. For moral speech there were differences between the Christians, who were more in favour of the freedom of moral speech (3.60), while the Muslims and the non-religious united in a more sceptical attitude (3.48). Politics were considered important to a larger extent by the Christians (2.90), and the Muslims (2.99), compared to the non-religious (2.78). Regarding social equality, the Muslims were the most positive (3.77), and the non-religious were the least positive (3.33). The Christian group were situated in-between (3.54). For the variable 
environment the Muslims were the least positive (3.43), followed by the Christians (3.61) and the non-religious (3.72).

To summarize these comparisons, it can be said that there were significant differences between the groups for all the items. In some cases (social equality, family values, and political interest) the Christian and the Muslim groups were more positive than the Non-religious. In other cases (abortion, environment) the Muslim group is the least positive, while the Non-religious group was the most positive and the Christian group in-between. In yet another case, the Muslim and the Non-religious groups turned out to be more sceptical of freedom of moral speech than the Christian group.

Hypothesis 1 concerned the idea that religiosity is closely linked to issues of family and morality, i.e. the private sphere rather than the public sphere. In the sense that the two religious groups received different scores on private issues, this hypothesis was partly confirmed. However, there was a stronger emphasis on social equality among the Muslims and Christians, and higher values for the right to work, which was not expected in the first hypothesis. The intriguing image of Muslims and Non-religious siding against too far-reaching freedom of moral speech is part of a more sensitive public sphere climate after the Muhammad caricatures and the hijab issue in Sweden and Norway in recent years. However, this finding that only partially confirms the first hypothesis might suggest that a more nuanced understanding of the relation between religiosity and political values is needed. This leads us to the second hypothesis, which stated that there would be a stronger relation between Muslim religiosity and social values than for Christian religiosity and social values. The second hypothesis was confirmed. There were minor but still significant differences between the outcome in the Christian and the Muslim groups, as the Muslim respondents was more negative to abortion and more in favour of family values than the Christian respondents. By checking differences between the Swedish and Norwegian samples, we find that the same pattern is valid in both samples. Even if there are minor fluctuations in exact numbers there are no differences for the overall results of the comparison.

\section{Step 2: Regression analysis}

In order to closer understand the impact of religiosity on attitudes towards human rights, we need to use a more accurate tool to measure this. As was previously outlined we used those same variables on religiosity mentioned earlier, and created an index for religiosity. This was done in order to enable the use of regression analysis to investigate exactly what effect - if any - religiosity would have for the attitudes towards human rights under scrutiny. The advantage of deploying multiple regression analysis here is that it enables us to study the effect of religiosity, controlling for other relevant variables. In table 3 , the adjusted $\mathrm{R}^{2}$ 's of the model are reported. From the table it is seen that the models used explains between 3 per cent and 17 per cent of the variance in the respective dependent variables. While there was some impact of religion it was quite limited, but at the same time there was also variation between the different independent variables as to how large (or rather, how modest) this effect was. 
Table 3: Adjusted $\mathbf{R}^{2}$, s from seven regression analyses. Dependent variables as listed. Independent variables: gender, parents' education level, political conversation at home, political preference, Christian Religiosity Index, Muslim Religiosity Index

\begin{tabular}{|l|r|}
\hline & Adj R $^{2}$ \\
\hline Abortion & .07 \\
\hline Family values & .13 \\
\hline Right to work & .08 \\
\hline Moral speech & .03 \\
\hline Politics important & .09 \\
\hline Social equality & .17 \\
\hline Environment & .03 \\
\hline
\end{tabular}

Which independent variables contribute to the model, for the various dependent variables? In table 4 we take a closer look at the effect of each of the included items. The standardized beta coefficients are reported along with their significance level. ${ }^{3}$

Table 4: Results of seven multiple regression analyses, dependent variables in columns. Standardized beta coefficients with levels of significance

\begin{tabular}{|c|c|c|c|c|c|c|c|}
\hline & 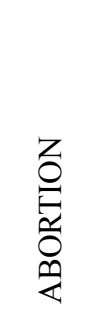 & 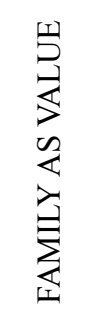 & $\begin{array}{l}\frac{1}{2} \\
0 \\
3 \\
0 \\
日 \\
\frac{1}{1} \\
0 \\
\frac{1}{2}\end{array}$ & 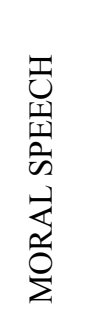 & 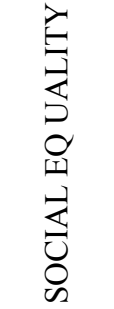 & 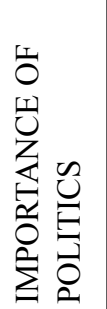 & 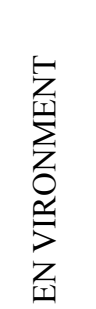 \\
\hline Gender $($ female $=1)$ & $.15 * * *$ & $.05^{*}$ & $.26 * * *$ & $.09^{* *}$ & $.29 * * *$ & $.08 * *$ & $.06^{*}$ \\
\hline Political conversation at home & $.09 * *$ & $.01^{\mathrm{ns}}$ & $.04^{\mathrm{ns}}$ & $.13 * * *$ & $.07 * *$ & $.27 * * *$ & $.10 * * *$ \\
\hline Political preference & $.02^{\mathrm{ns}}$ & $.05^{*}$ & $-.08^{* *}$ & $.01^{\mathrm{ns}}$ & $-.20 * * *$ & $-.06^{*}$ & $-.07 * *$ \\
\hline Parents' education level & $.03^{\mathrm{ns}}$ & $-.03^{\mathrm{ns}}$ & $.02^{\mathrm{ns}}$ & $.06^{*}$ & $-.00^{\mathrm{ns}}$ & $.06^{*}$ & $.09 * *$ \\
\hline Christian Religiosity Index & $-.12 * * *$ & $.25 * * *$ & $.01^{\mathrm{ns}}$ & $.07 * *$ & $.07 * *$ & $.04^{\mathrm{ns}}$ & $-.01^{\mathrm{ns}}$ \\
\hline Muslim Religiosity Index & $-.16^{* * *}$ & $.18^{* * *}$ & $.05^{\mathrm{ns}}$ & $.00^{\mathrm{ns}}$ & $.12 * * *$ & $.04^{\mathrm{ns}}$ & $-.06^{\mathrm{ns}}$ \\
\hline
\end{tabular}

Political preference: 5-point scale from leftist to rightist orientation

Table 4 shows that the two religiosity indexes have the largest effect on values related to the private sphere, namely abortion (-.12 and -.16) and family values (.25 and .18), respectively. For the scale right to work neither the Christian religiosity index (.01) nor the Muslim religiosity index (.05) had any significant effect when background variables were controlled for. The Christian religiosity index had a small effect on moral speech (.07). Both religiosity indexes have a small or moderate effect on the social equality index (.07 and .12 respectively). For importance of politics and for environment, respectively, the religiosity indexes had no significant effect. Among the background variables in the model, gender had effects on all items. Political conversation at home had effect 
both for abortion (considered belonging to the private sphere) and the items considered to belong to the public sphere. Political preference (scale 1-5, where 1 is left and 5 is right), had an effect on family values, social equality, importance of politics and environment. Parents' education level had an effect on moral speech, importance of politics and environment.

\section{Summary}

Summing up the analysis presented in Table 4, hypothesis 1 is confirmed in that religion in the form of religiosity indexes does have a greater effect on the issues related to the personal or private sphere than on the issues related to the public sphere. This result is congruent with the outcome of the comparison of the groups in table 2 . This means that the combination of comparing means (table 2) and regression analyses (tables 3 and 4 ) helped to support hypothesis 1 . However, hypothesis 2 was not very clearly confirmed, which is seen in table 4 . In 2 out of 7 cases the effect of Muslim religiosity index was higher than that of the Christian religiosity index. In 2 out of 7 cases the effect of the Christian religiosity index was higher than that of the Muslim religiosity index. Also in 3 of 7 cases there was no difference in effect between the Christian religiosity index and the Muslim religiosity index. Our interpretation of these results is, that it cannot really be said to be the case that the Muslim religiosity index is more closely related to the value areas we examined here, when controlling for the other variables in the model. After introducing the control variables, several of the differences between Christians and Muslims from table 1 disappeared or were qualified. Only the stronger relationship of the Muslim religiosity index to abortion, and social equality held up to closer analysis and control for background variables. Our interpretation is that 2 out of 7 possible cases is not a good enough outcome to bring hypothesis 2 'home'. By using both the group comparison in tables 1 and 2, and the regression analyses in tables 3 and 4 we have found that religiosity had effect on attitudes towards human rights related to the personal or private sphere, which can be linked to Dobbelaere's theory of compartmentalisation. There is, as we stated in hypothesis 1, a closer link between religion and issues of morality and family than between religion and work and political themes. This difference between different value domains can be interpreted as a sign of compartmentalisation. Regarding hypothesis 2, about the closer relationship between the Muslim religiosity index and other value areas than for Christian religiosity index, this was not confirmed.

A closer look was also taken comparing the outcome of regression analyses for each country. The overall picture was interestingly and as expected the same. In only a few instances there were noticeable differences: In the Norwegian data, political preference also had a positive effect on attitudes towards abortion, which was not the case in the Swedish data. In the Swedish data, the Christian religiosity index had a positive effect on moral speech - which was not the case in the Norwegian data. However these details do not alter the overall results of the regression analysis, and confirm the appropriateness of utilizing one aggregated data file. 


\section{Discussion}

What do these results mean and how can our results contribute to the theoretical discussion on the impact of religion on attitudes toward political values and attitudes towards human rights? At a micro level, compartmentalisation is said to constitute the psychological parallel to the macro-level differentiation between religious and secular institutions. Accordingly, religious differentiation «in mind» would mean increasing levels of compartmentalisation, while decreasing levels of compartmentalisation would point in the direction of de-differentiation or deprivatization. As there were signs of a closer relationship between religion and attitudes related to the private sphere than between religion and attitudes related to the public sphere we can say that this study has shown there was evidence of compartmentalisation. While, however, there was evidence of compartmentalisation, there was no evidence that there would be a different pattern of compartmentalisation among young Muslims in Norway and Sweden than among young Christians in the same countries.

It also needs to be noted that our results are valid for the items investigated here. The questionnaire used in the international research program Human Rights and Religion consisted of a number of items and it was, regrettably, not possible to include all of them in this article. To state a central but complex point briefly, of course the operationalisation and comparison of attitudes towards different human rights is important for further studies. As was touched upon in the account of the procedure, further development of the instruments used to grasp the multidimensional phenomenon of religion is also essential to future research. This is perhaps of particular interest since some sociologists of religion (i.e. Heelas and Woodhead 2005) stress the increasing individualization of religion taking place within many religious traditions, possibly changing the political consequences of a religious orientation.

\section{Conclusion}

If we now return to Pettersson's (2009) interesting results using World Values Survey data we claim that our results are in line with his. In our data on upper secondary school pupils in Sweden and Norway, there is support for Pettersson's critical discussion of Dobbelaere's theory, which calls for a more nuanced understanding of compartmentalisation. Our analysis of the data on attitudes towards human rights among upper secondary pupils showed that there still is a close relationship between religion and attitudes towards issues in the private sphere, such as abortion and family values. But at the same time it was not the case that religion had a larger effect among the Muslims than among the Christians regarding their attitudes towards issues more related to the public sphere. This could be because religion still is seen as a private matter in these two Scandinavian countries, or put in other terms, still compartmentalised to a personal sphere. Such an interpretation is supported by another study which showed that among Muslim immigrants in Western Europe, values related to family and private moral issues, linked to primary socialisation were retained, while values related to work and the economy and public sphere issues, stemming from secondary socialisation altered 
as a result of migration to Western Europe (Pettersson 2007). The second hypothesis suggested that there are different patterns of compartmentalisation among Christians and Muslims. Our study showed: 'No, not really in these data'. One could of course argue that quantitative data is not nuanced enough to fully detect the different interpretations of human rights in the three lifeview groups. As suggested by some qualitative studies (Berglund 2012; Synnes 2010), privatization is a complex process consisting on several dimensions that is not captured fully by the term «compartmentalisation». The same can be true when it comes to interpretations of human rights and their consequences in society. Christians, Muslims and Non-religious young people may have different meanings of political and civil rights. This is one possible explanation for the lack of support for hypothesis 2 in our data. In future research, quantitative studies such as ours need to be supplemented by studies that include the use of qualitative data. Further studies are needed using these and other samples and preferably combine quantitative and qualitative data to further elaborate on how the relationship between religion and political values best should be understood and how these issues evolve.

\section{Notes}

1 This article has been written within the framework of the multidisciplinary research programme Impact of Religion: Challenges for Society, Law and Democracy, at Uppsala University and funded by the Swedish Research Council 2008-2018.

2 The constructions of the scales are explained in the text. The scale called «Moral speech» is the one that is least self-evident. It is composed of attitudes towards the two statements «The community's moral standards should be critically debated in schools» and «Children should be free to discuss all moral ideas and subjects in schools, no matter what».

$3 * * * \mathrm{p}<.001 ; * * \mathrm{p}<.01 ; * \mathrm{p}<.05$.

\section{References}

Berglund J. 2012. Islam som resurs? (Islam as a resource?). In Religion som resurs? Existentiella frågor och värderingar i ungas svenskars liv (Religion as a resource? Existential issues and values in the lives of young Swedes), Mia Lövheim and Jonas Bromander (eds.). Skellefteå: Artos.

Botvar, Pål Ketil 1993. Religion uten kirke: Ikke-institusjonell religiøsitet i Norge, Storbritannia og Tyskland (Religion outside a Church: Non-institutionalized religiosity in Norway, Britain, and Germany). Diaforsk report nr. 10/1993. Diakonhjemmets høgskole.

Botvar, Pål Ketil and Ulla Schmidt (eds.) 2010. Religion i dagens Norge. Mellom sekularisering og sakralisering (Religion in Norway today. Between secularization and sacralization). Oslo: Universitetsforlaget.

Bäckström, Anders, Grace Davie, Ninna Edgardh and Per Pettersson (eds.) 2011. Welfare and Religion in Europe, Volume 2. Gendered, Religious and Social Change. Farnham: Ashgate.

Cairo Declaration on Human Rights in Islam, Aug. 5, 1990, U.N. GAOR, World Conf. on Hum. Rts., 4th Sess., Agenda Item 5, U.N. Doc. A/CONF.157/PC/62/Add.18 (1993) [English translation]. 
Casanova, José 1994. Public Religions in the Modern World. Chicago: Chicago University Press.

Dobbelaere, Karel 1981. Secularization: a multi-dimensional concept. Current Sociology 29(2).

Dobbelaere, Karel 1998. Secularization. In Encyclopedia of Religion and Society, W. H. Swatos and P. Kivisto (eds.). London: Sage.

Dobbelaere, Karel 2002. Secularization: An Analysis at Three Levels, Gods, Humans and Religions. Brussels; Oxford: Peter Lang.

Field, Andy 2010. Discovering Statistics Using SPSS, third edition. London, Thousand Oaks, New Delhi: Sage.

Gustafsson, Göran, and Thorleif Pettersson (eds.) 2000. Folkkyrkor och religiös pluralism - den nordiska religiösa modellen (Folk churches and religious pluralism - the Nordic religious model). Stockholm: Verbum.

Hagevi, Magnus 2012. Är religion och politik skilda världar för svenska ungdomar? (Are religion and politics separate worlds for Swedish youth?). In Religion som resurs? Existentiella frågor och värderingar i ungas svenskars liv (Religion as a resource? Existential issues and values in the lives of young Swedes), Mia Lövheim and Jonas Bromander (eds). Skellefteå: Artos.

Heelas, Paul and Linda Woodhead 2005. The Spiritual Revolution: Why Religion is Giving Way to Spirituality. Malden, Mass.: Blackwell

Jacobsen Christine 2002. Tilhørighetens mange former. Unge muslimer i Norge (Many ways of belonging: Young Muslims in Norway). Oslo: Unipax.

Kay, William K. and Hans-Georg Ziebertz 2006. A Nine Country Survey of Youth in Europe: Selected Findings and Issues. British Journal of Religious Education 28 (2):119-129.

Lövheim, Mia and Jonas Bromander (eds.) 2012. Religion som resurs? Existentiella frågor och värderingar $i$ ungas svenskars liv (Religion as a resource? Existential issues and values in the lives of young Swedes). Skellefteå: Artos.

Pettersson Thorleif 2007. Muslim Immigrants in Western Europe: Persisting Value Differences or Value Adaption? In Values and Perceptions of the Islamic and Middle Eastern Publics, Mansour Moaddel (ed.). New York: Palgrave Macmillan. (Also available in electronic edition 2010).

Pettersson, Thorleif 2009. Religious Commitment and Socio-Political Orientations: Different Patterns of Compartmentalisation Among Muslims and Christians? In Routledge Handbook of Religion and Politics, Jeff Haynes (ed.), 246-270. New York: Routledge.

Rasmussen, Tarald 2012. Norge (Norway). In Store norske leksikon (Great Norwegian encyclopedia) [online]. Available from: http://snl.no/Norge/religion [Accessed 2 February 2012].

Robbins, Mandy and Leslie J. Francis 2010. The Teenage Religion and Values Survey in England and Wales: An overview. British Journal of Religious Education 32:307-320.

Synnes, Ronald Mayora 2010. Religiøsitet blant unge muslimer og kristne i Oslo. En komparativ analyse av åtte unge muslimer og kristnes fortellinger i et kjønnsperspektiv (Religiosity among young Muslims and Christians in Oslo. A comparative study of eight young Muslims and Christians' stories in a gender perspective). Unpublished Master's thesis in Religion, Society and Global Issues. Det teologiske menighetsfakultet.

Turner, Bryan S. 1993. Outline of a Theory of Human Rights. Sociology, 27: 485-512.

Turner, Bryan 2006. Vulnerability and Human Rights. University Park, PA: Penn State University Press.

Valk, Pille, Gerdien Bertram-Troost, Markus Friederici and Céline Béraud 2009. Teenagers' Perspectives on the Role of Religion in their Lives, Schools and Societies: A European 
Quantitative Study. Religious Diversity and Education in Europe, REDCo, Vol. 7. Münster: Waxmann.

Van der Ven, Johannes A. 2010. Religious Rules or Human Rights? Leiden: Brill.

Van der Ven, Johannes A. and Hans-Georg Ziebertz (eds.) 2012. Tensions within and between Religions and Human Rights. Leiden: Brill.

Wilson, Bryan 1966. Religion in Secular Society: A Sociological Comment. London: Watts.

Ziebertz, Hans-Georg, and William K. Kay 2005. Youth in Europe: Correspondance and Diversity. In Youth in Europe I: Life Perspectives. An international empirical Study about Life Perspectives, H.-G. Ziebertz and W. K. Kay (eds). Münster, Hamburg, London: LIT. 